\title{
Kemampuan Serbuk Serai (Cymbopogon Citratus) Menekan Peningkatan Total Bakteri Dan Keasaman (Ph) Dendeng Domba Selama Penyimpanan
}

\author{
K. Suradi ${ }^{1 \text { a }}$, J. Gumilar ${ }^{1}$, G. H. R. Yohana ${ }^{1}$, A. Hidayatulloh ${ }^{1}$ \\ ${ }^{I}$ Laboratorium Teknologi Pengolahan Produk Peternakan, Fakultas Peternakan, Universitas Padjdajaran \\ aemail:kusmajadi@gmail.com
}

\begin{abstract}
Abstrak
Serai memiliki potensi sebagai bahan alami untuk menekan peningkatan bakteri dendeng domba, karena senyawa aktifyang dikandung serai, yaitu tanin, flavonoid, minyak essensial, alkoloid, dan saponin bersifat antibakteri, sehingga berimplikasi dihambatnya peningkatan $\mathrm{pH}$. Penelitian dilaksanakan di Laboratorium Teknologi Pengolahan Produk Peternakan Fakultas Peternakan Universitas Padjadjaran dengan tujuan untuk mengetahui dan mendapatkan konsentrasi serbuk serai yang dapat menekan total bakteri dan peningkatan $\mathrm{pH}$ dendeng domba. Penelitian dilakukan secara eksperimen menggunakan Rancangan tersarang (nested), yaitu waktu (awal penyimpanan dan seminggu penyimpanan) yang tersarang dalam 4 konsentrasi serai, yaitu $0,5 \%$, konsentrasi serai 1,0\%, konsentrasi serai 1,5\%, dan konsentrasi serai $2 \%$. Setiap perlakuan mendapat pengulangan 5 kali. Analisis sidik ragam digunakan untuk mengetahui pengaruh konsentrasi serbuk serai terhadap $\mathrm{pH}$ dan total bakteri dendeng domba, untuk mengetahui perbedaan antar perlakuan digunakan Uji Jarak Berganda Duncan. Konsentrasi bubuk serai tidak berpengaruh terhadap $\mathrm{pH}$ dan total bakteri dendeng daging domba Waktu dalam konsentrasi bubuk serai berpengaruh terhadap $\mathrm{pH}$ dan total bakteri, kecuali waktu dalam konsentrasi bubuk serai $1,5 \%$ tidak berpengaruh terhadap $\mathrm{pH}$ dendeng daging domba.
\end{abstract}

Kata kunci: Dendeng, Serai, pH, danTotal Bakteri

\section{The Ability of Lemongrass Powder (Cymbopogon citarus) to Inhibit Total Bacteria and Acidity (pH) of Lamb Jerky During Storage}

\begin{abstract}
Lemongrass has the potential as a natural ingredient to determine the bacteria of lamb jerky, because the active compounds contained that is, tannins, flavonoids, essential oils, alkoloid, and saponins are antibacterial, thus increasing the $\mathrm{pH}$ implicated. The research was carried out in the Laboratory of Processing Technology of Research Result of the Faculty of Animal Husbandry of Padjadjaran University with the aim to find out the concentration of lemongrass powder that can inhibit the total bacteria and increase of $p H$ lamb jerky. Experimental research was used nested design, was time (initial storage and storage week) nested in 4 lemongrass powder concentrations,ie $0.5 \%, 1.0 \%, 1.5 \%$, and concentration $2 \%$. Each treatment was replicated five time. Analysis of variance to determine the effect of powder concentration of lemongrass powder $\mathrm{pH}$ and the number of bacteria lamb jerky. Duncan Multiple Range Test was used to know differences between treatments. The result showed concentration of lemongrass powder had no effect on $\mathrm{pH}$ and total bacteria of lamb jerky, except in the concentration of 1,5\% lemongrass powder not significant to the $\mathrm{pH}$ of lamb jerky.

Keywords: Jerky, Lemongrass, $\mathrm{pH}$, and Total Bacteria

\section{Pendahuluan}

Daging domba merupakan media yang baik bagi pertumbuhan dan perkembang biakan bakteri, sehingga mudah rusak tanpa penanganan dan pengawetan yang baik. Oleh karena itu untuk memperpanjang masa simpan

daging domba perlu dilakukan upaya pengawetan melalui pembuatan dendeng,sekaligus menutupi aroma daging domba yang kurang disukai sebagian orang, karena dalam pembuatan dendeng ditambahkan bumbu.
\end{abstract}


Dendeng merupakan salah satu jenis makanan yang menerapkan teknologi pengeringan untuk mengurangi kadar air dalam bahan pangan sampai dianggap cukup aman untuk menekan pertumbuhan dan perkembang biakan bakteri. Kadar air dendeng yang rendah mengakibatkan daya simpannya dapat diperpanjang dibandingkan dengan daging segar, selain itu masa simpannya dapat lebih diperpanjang lagi bila dalam pembuatannya digunakan bumbu yang mempunyai kemampuan untuk menghambat perttumbuhan dan perkembang biakan bakteri.

Dendeng domba memiliki rataan $\mathrm{pH}$ sebesar 5,94 (Suharyanto, dkk., 2008). Hasil penelitian menjelaskan bahwa semakin lama penyimpanan dendeng akan diikuti dengan peningkatan $\mathrm{pH}$ karena penetrasi air bebas di udara (Rusman, dkk., 2013). Penetrasi air bebas dari udara ke dalam dendeng membuat dendeng menjadi lembab dan menjadi media yang cocok bagi perkembangan bakteri. Penyimpanan dendeng sapi asap yang dikemas dan disimpan pada lemari es pada suhu $6^{\circ} \mathrm{C}$ selama nol, satu, dan dua minggu menunjukkan pertumbuhan bakteri aerob, Escherichia coli, dan Staphylococcus $s p$, dan terjadi peningkatan setiap minggunya (Harsojo dan Made, 2014). Hasil penelitian tersebut mengindikasikan perlunya penggunaan bumbu yang mengandung bahan aktif, diantaranya serai untuk memperpanjang masa simpan.

Penggunaan serai (Cymbopogon citrates) sebagai bumbu untuk pembangkit cita rasa dan dipercaya pula dapat dimanfaatkan dalam pengobatan tradisional, sehingga serai dapat digolongkan sebagai bahan pengawet alami, karena seraimengandung senyawa fitokimia antara lain saponin, tanin,alkaloid, flavonoid dan minyak atsiri (Hamza, dkk., 2009). Berbagai kandungan senyawa aktif tersebut mengindikasikan serai memiliki aktivitas antibakteri yang cukup besar, khususnya kandungan minyak atsiri yang terdapat didalamnya.Perkembangan dan pertumbuhan bakteri yang terhambat oleh senyawa aktif serai ini dapat memengaruhi daya awet dengan cara mengurangi kecepatan perubahan $\mathrm{pH}$ daging, namunkemampuan serai untuk menghambat aktivitas bakteri tergantung pada konsentrasi yang digunakan.
Serai kaya akancitral, yang biasa digunakan oleh industri pengharumdan farmasi, dan senyawa-senyawa bioaktif (senyawa flavonoid dan vitamin C). Senyawa flavonoid alami ini lebih harum dan lebih menarik perhatian tidak hanya karena bahan-bahan antioksidan, tetapi juga agen anti kanker dan anti iflamasi karena efek dari anti oksidasi lemak serai (Martin,dkk.,2002).Senyawa yang ada dalam serai selain flavonoid adalah licochacone A dan licochaconeB yang memiliki aktivitas antioksidan yang sama dengan glaberen dan tiga kali lebih aktif dibandingkan dengan vitamin E(Abd-El Fattah, dkk., 2010).

Ekstrak serai menunjukan potensi besar sebagai zat antibakteri yang dapat menekan aktivitas Bacillus cereus, Salmonella typhimurium dan Staphylococcus aureus, hal ini mengindikasikan kemungkinan penggunaan tanaman obat sebagai agen antibakteri alami (Ibrahim, dkk., 2013). Hasil penelitian menunjukkan bahwa penambahan minyak serai konsentrasi $1,5 \%$ menghasilkan total bakteri terendah dan kenaikan $\mathrm{pH}$ yang lebih lambat selama penyimpanan sampai enam hari pada daging sapi giling dibandingkan pada konsentrasi $0.5 \%$ dan 1,0\% (Amany, dkk., 2010).

Penggunaan serai telah dilakukan dalam pembuatan burger ayam dengan penambahan serai sebanyak $0,25 \%$ menghasilkan total bakteri terendah selama penyimpanan sembilan hari dibandingkan dengan yang tidak diberi ekstrak serai (Ibrahim, dkk., 2013). Hal yang sama pada pembuatan burger sapi bahwa penggunaan serai sebanyak $2 \%$ dapat mengurangi aktivitas bakteri selama penyimpanan dengan jumlah bakteri terendah dan memberikan akseptabilitas terbaik, dibandingkan dengan konsentrasi $1 \%$ dan $0,5 \%$ (Hussein, dkk., 2015).Penggunaan serai pada pembuatan burger dan daging giling dapat diterapkan pula dalam pembuatan dendeng domba sekaligus mengurangi aroma khas daging domba karena senyawa aktif yang terkandung seperti senyawa saponin dan flavonoid.

\section{Materi dan Metode}

Materi yang digunakan, yaitu daging domba bagian paha dari ternak domba berumur 12 bulan dengan berat karkas 9,8 kgdan bumbu yaitu serai, garam, bawang putih, ketumbar, 
lengkuas dan gula merah. Bahan kimia untuk Uji Bakteri dan $\mathrm{pH}$, yaituMedia agar PCA (Plate Count Agar), $\mathrm{NaCl}$ fisiologis, aquades dan alkohol.

Pembuatan dendeng domba menggunakan resep mengacu pada Lisdiawati (2004) dan Mega, dkk., (2009) pada Tabel 1.

Pembuatan bubuk serai menggunakan metode Olonrunsanya, dkk., (2010) dengan modifikasi pada penyaringan bubuk serai. Serai dicuci dengan air mengalir, lalu dipotong-potong menjadi beberapa bagian. Kemudian serai dikeringkan dengan oven dengan panas $40^{\circ} \mathrm{C}$ selama dua hari.Serai yang telah kering dihaluskan menggunakan blender.Serai hasil penghancuran dengan blender disaring menggunakan saringan berukuran 18 mesh lalu dilanjutkan dengan ukuran 30 mesh.

Proses pembuatan dendeng domba melalui tahapan pemotongan daging bentuk dadu, kemudian digiling dan dicampurkan bumbu yang telah dihaluskan. Bubuk serai dengan konsentrasi $0,5 \%, 1,0 \%, 1,5 \%$, dan $2 \%$ ditambahkan pada adonan, kemudian adonan dendeng dicetak pada loyang dengan tebal \pm 3 mm.Adonan dendeng domba diuapkan airnya menggunakan oven pada suhu $80^{\circ} \mathrm{C}$ selama 3 jam, kemudian dendeng dikemas plastik polyethylene dan dilakukan penyimpanan pada kisaran suhu $20-22{ }^{\circ} \mathrm{C}$ selama 7 hari. Pengujian uji $\mathrm{pH}$ dan total bakteri dendeng domba dilakukan pada awal penyimpanan dan akhir penyimpanan.

Penelitian dilakukan secara eksperimen menggunakan rancangan tersarang (nested) perlakuan waktu (0 hari dan 7 hari) tersarang di dalam perlakuan konsentrasi serai $(0,5 \%, 1,0 \%$, $1,5 \%$, dan $2 \%$ ) dengan pengulangan 5 kali.Hasil uji kemudian dianalisis menggunakan sidik ragam untuk mengetahui pengaruh perlakuan terhadap variable yang diukur, sedangkanuntuk mengetahui perbedaan antar perlakuan dilakukan uji jarak berganda Duncan (Sudjana, 2000). Variabel yang diukur adalah $\mathrm{pH}$ dan total bakteri. Pengukuran $\mathrm{pH}$ dendeng domba mengacu pada Denny dan Trioso(2009), sedangkan pengukuran total bakteri dendeng dombamengacu pada Badan Standardisasi Nasional(2006).

\section{Hasil dan Pembahasan}

Hasil penelitian pengaruh perlakuan terhadap $\mathrm{pH}$ dan total bakteri dendeng domba menujukkan bahwa konsentrasi bubuk sereh tidak berpengaruh nyata terhadap penurunan $\mathrm{pH}$ dan peningkatan jumlah bakteri (Tabel 2), tetapi waktu dalam konsentrasi bubuk sereh nyata $(\mathrm{P}<0,05)$ berpengaruh terhadap penurunan $\mathrm{pH}$ dan jumlah bakteri (Tabel 3).

Tabel 1. Resep Pembuatan Dendeng Domba

\begin{tabular}{clc}
\hline No & Bahan & Persentase (\%) \\
\hline $\mathbf{1}$ & Daging domba & 61,5 \\
$\mathbf{2}$ & Gula merah & 30 \\
$\mathbf{3}$ & Ketumbar & $0,02^{*}$ \\
$\mathbf{4}$ & Lengkuas & $0,05^{*}$ \\
$\mathbf{5}$ & Bawang putih & 1 \\
$\mathbf{7}$ & Garam & 2 \\
\hline
\end{tabular}

Sumber: Lisdiawati (2004); * Mega, dkk., (2009)

Tabel 2. Pengaruh Konsentrasi Bubuk Serai Terhadap pH dan Total Bakteri Dendeng Domba

\begin{tabular}{lcccc}
\hline \multirow{2}{*}{ Variabel } & \multicolumn{4}{c}{ Konsentrasi Bubuk Serai } \\
\cline { 2 - 5 } & 0,5 & 1,0 & 1,5 & 2,0 \\
\hline $\mathrm{pH}$ & $5,69 \mathrm{a}$ & $5,68 \mathrm{a}$ & $5,72 \mathrm{a}$ & $5,71 \mathrm{a}$ \\
Total Bakteri(cfu/g) & $5,9 \times 10^{4} \mathrm{a}$ & $6,2 \times 10^{4} \mathrm{a}$ & $5,3 \times 10^{4} \mathrm{a}$ & $5,4 \times 10^{4} \mathrm{a}$ \\
\hline
\end{tabular}

Keterangan : Huruf yang sama kearah baris menunjukkan tidak berbeda nyata $(\mathrm{P}>0,05)$ 
Data pada Tabel 2 menunjukkan bahwa nilai $\mathrm{pH}$ dendeng domba hasil penelitian pada kisaran 5,68 - 5,76 sesuai dengan penelitian sebelumnya yaitu pada kisaran 5,61- 5,80 (Dierschke, dkk. 2010) dan hasil penelitian Lonnecker, dkk. (2010) bahwa pH dendeng dari berbagai industri rata-rata sebesar 5,85.Konsentrasi bubuk sereh tidak memberikan efek yang nyata terhadap $\mathrm{pH}$ karena perbedaan konsentrasi $\mathrm{pH}$ daging domba dan bubuk serai yang kecil, yaitu bubuk serai memiliki $\mathrm{pH} 5,45$ sedangkan daging domba memiliki $\mathrm{pH}$ 5,94.

Total bakteri dendeng domba hasil penelitian pada kisaran $5,3 \times 10^{4}$ sampai $6,2 \times 10^{4}$ memenuhi standar SNI ditetapkan oleh Badan Standardisasi Nasional (2009) yaitu 1 x $10^{5} \mathrm{CFU} / \mathrm{g}$. Total bakteri dendeng domba tidak memberikan perbedaan yang nyata pada berbagai perlakuan bubuk serai, menunjukkan bahwa senyawa aktif bubuk serai dengan konsentrasi $0,5 \%$ sampai $2,0 \%$ belum mampu untuk menekan jumlah bakteri yang ada pada dendeng domba, sehingga pada perlu dilakukan penelitian yang sama dengan tingkat penggunaan bubuk serai yang lebih tinggi.

Data pada Tabel 3 menunjukkan bahwa waktu penyimpanan dendeng domba selama 7 hari nyata $(\mathrm{P}<0,05)$ lebih rendah dibandingkan dengan $\mathrm{pH}$ awal penyimpanan (0 hari), sedangkan terhadap total bakteri menunjukkan bahwa penyimpanan selama 7 hari nyata $(\mathrm{P}<0,05)$ lebih banyak dibandingkan dengan awal penyimpanan (0 hari). Hal ini disebabkan selama penyimpanan gula merah yang ditambahkan sebagai bumbu sebanyak 30\% mengalami fermentasi, sehingga terjadi penurunan $\mathrm{pH}$.Bakteri asam laktat menggunakan hasil metabolisme karbohidrat menjadi asam laktat yang menyebabkan keadaan asam atau $\mathrm{pH}$ menurun. Sebagaimana dikemukakan oleh Soeparno (2009) bahwa hasil metabolisme dikonversikan ke asam laktat oleh mikrorganisme asam laktat homofermentatif, misalnya Strepococcus, Pediococcus, Microbacterium dan sejumlah Lactobacillus. Hasil fermentasi ini menyebabkan $\mathrm{pH}$ daging menjadi lebih rendah (Lechowich, 1971).

Proses fermentasi berakaitan dengan aktifitas dan perkembang biakan bakteri yang pada akhirnya akan berpengaruh terhadap meningkatnya total bakteri dendeng daging domba diperlihatkan dengan meningkatnya jumlah bakteri yang nyata $(\mathrm{P}<0,05)$ selama penyimpanan 7 hari dibandingkan dengan awal penyimpanan (0 hari).Hasil penelitian ini sesuai yang dilakukan oleh Jahidin (2014), bahwa jumlah total koloni bakteri selama penyimpanan mengalami peningkatandiduga dapat dipengaruhi oleh adanyatambahan air dari lingkungan produk sehingga menyebabkan terjadinya kenaikanjumlah total koloni bakteri. Peningkatan total bakteri setelah penyimpanan tujuh hari pada dendeng domba masih sesuai dengan syarat yang ditetapkan oleh Badan Standardisasi Nasional (2009) yaitu batas total bakteri pada dendeng adalah 1 x $10^{5} \mathrm{CFU} / \mathrm{g}$.

Analisis statistik pengaruh waktu dalam perlakuan pada konsentrasi yang berbeda terhadap $\mathrm{pH}$ dan total bakteri tercantum pada Tabel 4.

Data pada Tabel 4 menunjukkan bahwa pengaruh lama penyimpanan 7 hari dibandingkan dengan 0 hari terhadap $\mathrm{pH}$ dendeng domba dalam konsentrasi bubuk serai $0,5 \%, 1,0 \%$ dan $2,0 \%$ nyata lebih rendah $(\mathrm{P}<0,05)$, tetapi tidak memberikan pengaruh yang nyata dalam konsentrasi bubuk serai $1,5 \%$. Perbedaan yang nyata $\mathrm{pH}$ dendeng domba disebabkan selama penyimpanan terjadi proses fermentasi gula menghasilkan asam (Lehninger, 1994). Asam adalah produk metabolit primer yang dihasilkan mikroba (Srikandi Fardiaz, 1992), sedangkan penurunan $\mathrm{pH}$ yang tidak nyata pada konsentrasi serai $1,5 \%$ diduga karena pada konsentrasi tersebut terjadi penurunan aktifitas bakteri dalam melakukan fermentasi.

Tabel 3. Pengaruh Waktu dalam Konsentrasi Terhadap pH dan Jumlah Bakteri

\begin{tabular}{lcc}
\hline \multirow{2}{*}{ Variabel } & \multicolumn{2}{c}{ Lama Penyimpanan pada berbagai Konsentrasi } \\
\cline { 2 - 3 } & Awal $(0$ hari $)$ & Seminggu $(7$ hari $)$ \\
\hline $\mathrm{pH}$ & $5,74 \mathrm{a}$ & $5,67 \mathrm{~b}$ \\
Total Bakteri $(\mathrm{cfu} / \mathrm{g})$ & $4,5 \times 10^{4} \mathrm{a}$ & $6,9 \times 10^{4} \mathrm{~b}$ \\
\hline Keterangan $:$ nilai & &
\end{tabular}

Keterangan : nilai yang diikuti dengan huruf berbeda kearah baris menunjukkan berbeda nyata $(\mathrm{P}<0,05)$ 
Tabel 4.Pengaruh Waktu dalam Konsentrasi Berbeda Terhadap pH dan Jumlah Bakteri

\begin{tabular}{lcccccccc}
\hline & \multicolumn{7}{c}{ Lama Penyimpanan dalam Konsentrasi Berbeda } \\
\cline { 2 - 9 } \multicolumn{1}{c}{ Variabel } & \multicolumn{2}{c}{0,5} & \multicolumn{4}{c}{1,5} & \multicolumn{2}{c}{2} \\
\cline { 2 - 9 } & $0 \mathrm{H}$ & $7 \mathrm{H}$ & $0 \mathrm{H}$ & $7 \mathrm{H}$ & $0 \mathrm{H}$ & $7 \mathrm{H}$ & $0 \mathrm{H}$ & $7 \mathrm{H}$ \\
\hline $\mathrm{pH}$ & $5.74 \mathrm{a}$ & $5.65 \mathrm{~b}$ & $5.72 \mathrm{a}$ & $5.64 \mathrm{~b}$ & $5.74 \mathrm{a}$ & $5.70 \mathrm{a}$ & $5.75 \mathrm{a}$ & $5.66 \mathrm{~b}$ \\
Total Bakteri(x 10 $\left.10^{4} \mathrm{cfu} / \mathrm{g}\right)$ & $4,70 \mathrm{a}$ & $7,10 \mathrm{~b}$ & $5,00 \mathrm{a}$ & $7,50 \mathrm{~b}$ & $3,90 \mathrm{a}$ & $6,60 \mathrm{~b}$ & $4,30 \mathrm{a}$ & $6,50 \mathrm{~b}$ \\
\hline
\end{tabular}

Keterangan : huruf yang sama kearah baris pada kolom konsentrasi yang sama menunjukkan tidak berbeda nyata $(\mathrm{P}>0,05)$.

$\mathrm{H}$ : hari

Berdasarkan total bakteri menunjukkan bahwa waktu penyimpanan selama 7 hari dalam berbagai konsentrasi serai nyata $(\mathrm{P}<0,05)$ meningkatkan total bakteri dendeng domba. Hal ini disebabkan selama penyimpanan terjadi terjadi keseimbangan, dendeng dengan kadar air yang rendah akan menyerap air dari udara sekitar sehingga terjadi peningkatan kelembaban dendeng yang akan mempercepat pertumbuhan bakteri sehingga terjadi peningkatan jumlah total bakteri di dalam dendeng selama 7 hari penyimpanan.

\section{Kesimpulan}

Berdasarkan hasil analisis statistik dan pembahasan dapat dikemukakan kesimpulan bahwa :

1. Konsentrasi bubuk serai tidak berpengaruh terhadap $\mathrm{pH}$ dan total bakteri dendeng daging domba

2. Waktu dalam konsentrasi bubuk serai berpengaruh terhadap $\mathrm{pH}$ dan total bakteri, kecuali waktu dalam konsentrasi bubuk serai $1,5 \%$ tidak berpengaruh terhadap $\mathrm{pH}$ dendeng daging domba.

\section{Daftar Pustaka}

Abd-El Fattah, S.M., Y.H. Abo sree., Bayoum, H.M., Eissa, H. A. (2010). The Use of Lemongrass Extracts as Antimicrobial and Food Additive Potential in Yoghurt. J. Am. Sci., 6:11. 582-594.

Amany, M. Salem. , Reham, A. Amin and Gehan, S. A. Afifi. (2010). Studies on Antimicrobial and Antioxidant Efficiency of SomeEssential Oils in Minced Beef. Journal of American Science. 6:12. 695-698.

Badan Standardisasi Nasional. (2008). Metode pengujian cemaran mikroba dalam daging, telur dan susu, serta hasil olahannya- SNI 2897:2008. BSN: Jakarta.

Denny dan Triyoso. (2009). Penuntun Praktikum Higiene Pangan Asal Hewan. Departemen Ilmu Penyakit Hewan dan Kesmavet. Fakultas Kedokteran Hewan IPB. 10-13.

Hamza, I. S., Sundus, H. A., and Hussaine, A. (2009). Study the Antimicrobial Activity of Lemon Grass Leaf Extracts. 2:1. 134136.

Harsojo, dan Made S.K. (2014). Keanekaragaman Bakteri Serta Kandungan Unsur Mikrodan Logam yang Dianalisis Secara Teknik Nuklir padaBeberapa Makanan Olahan Asap.Jurnal Ilmiah Aplikasi Isotop dan Radiasi. A Scientific Journal for The Applications of Isotopes and Radiation. 10: 2. 95-98.

Hussein, Sanna A., Shahin, M.F.S.A., and Masoud, M.R.M. (2015). Effect of Using Lemongrass and Thyme on Some Beefburger Characteeristics. Egypt. J. Agric. Res.,93 (1). 141-142.

Ibrahim, Hayam M., Ferial M. Abu Salem. (2013). Effect of Adding Lemongrass and Lime Peel Extracts on Chicken Patties Quality. Journal of Applied Sciences Research, 9(8). 5036.

Lehninger, A. (1994). Dasar-Dasar Biokimia.

Penerbit Erlangga, Jakarta

Lisdiawati, M. (2004). Sifat Fisik, Kimia dan Organoleptik Dendeng Kelinci dengan Bahan Pengasap Berbeda. Fakultas Peternakan. Institut Pertanian Bogor :Bogor.

Martin, F. R., Frutos, M. J. Pérez J. A., Alvarez, F., Martinez, S, and Tel Rio J. A. (2002). Flavonoids as Neutraceutical: Structural Related Antioxidant 
Properties and Their Role on Ascorbic Acid Preservation. In: Atta Ur-Rahman (Ed.). 2001. Studies in natural products chemistry. 26. 324-389.

Mega, Olfa, Warnoto, dan Dewi Bintang Castika. (2009). Pengaruh Pemberian Jahe Merah (Zingiber officinale Rosc) terhadap Karakteristik Dendeng Daging Ayam Petelur Afkir. Jurnal Sains Peternakan Indonesia 4: 2. 109.

Olorunsanya, A.O., Olorunsanya E.O., Bolu, S.A.O., Adejumobi, C. T. and Kayode, R.M.O. (2010). Effect of Graded Levels of Lemongrass (Cymbopogon citratus) onOxidative Stability of Raw or Cooked Pork Patties. Pakistan Journal of Nutrition. 9:5. 467.
Rusman, Marcus Veerman, dan Setiyono. (2013). Pengaruh Metode Pengeringan dan Konsentrasi Bumbu serta Lama Perendaman dalam Larutan Bumbu terhadap Kualitas Fisik dan Sensori Dendeng Babi.Buletin Peternakan Vol. 37(1). 27-30.

Sudjana. (2000). Desain dan Analisis Eksperimen, Edisi IV Tarsito, Bandung.

Suharyanto, R. Priyanto, dan E. Gunardi. (2008). Sifat Fisiko-Kimia Dendeng Daging GilingTerkait Cara Pencucian (Leaching) Dan Jenis Daging Yang Berbeda. Jurnal Media Peternakan 31. 101.

Srikandi Fardiaz. (1992). Mikrobiologi Pangan I. Jakarta: Gramedia Pustaka Utama. 